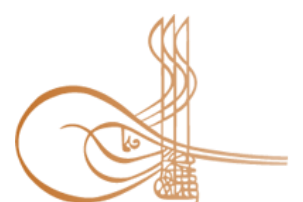

www.turkishstudies.net/social
Turkish Studies - Social Sciences

eISSN: 2667-5617

Research Article / Araștırma Makalesi

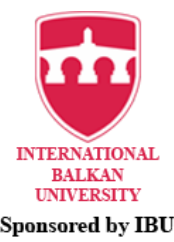

Sponsored by IBU

\title{
Müşteri Memnuniyeti ve Müşsteri Sadakati Oluşturmada Satış Sonrası Destek Hizmetleri ve Müşteri İlişsileri Yönetiminin Rolü
}

\author{
After-Sales Support Services and The Role of Customer Relationship Management On Customer \\ Satisfaction and Building Customer Loyalty
}

\author{
Gülşah Gençer Çelik*
}

\begin{abstract}
The research aims to determine the effect of customer relations management and after-sales support services on customer satisfaction and customer loyalty in the white goods sector. The sample of the research consists of 517 customers who benefited from after-sales support services. Questionnaire forms were used to collect the research data. The questionnaire form used in the study was deemed appropriate according to Beykent University Rectorate's ethics committee decision dated 01.06.2020. The analysis of the obtained data was carried out via the SPSS 25 package program and SPSS Process 2.16 macro. As a result of the analyzes, it was determined that after-sales support services and customer relationship management had a positive effect on customer satisfaction and customer loyalty. Also, it has been determined that customer satisfaction has a partial mediation effect on the effect of after-sales support services and customer relationship management on customer loyalty. When the research results are examined in general; Proper perception of after-sales support services to be applied in the white goods industry and proper management of customer relations ensure that customers' satisfaction levels are increased, and customer loyalty is created accordingly. When the findings obtained in the research and the results obtained in the literature are compared, it is seen that the bilateral relations between the variables are similar. The findings of the research can present results for the white goods sector and Istanbul. When the researches in the literature are examined, it is seen that after-sales support services, customer relationship management, customer satisfaction, and customer loyalty relations are not examined for the white goods sector. The scope of the research and the results obtained are different from similar researches in the literature.
\end{abstract}

Structured Abstract: Introduction and purpose: Customer management practices cover the activities carried out to obtain value for life from customers. Thus, it is thought that the customer will not be preferred from competitors, and customer satisfaction and loyalty will be provided with personalized services. Also, the satisfaction of customers who have chosen the company at least once and who need after-sales support services in the use of products and services is essential in terms of customer loyalty. The research aims to determine the effect of after-sales support services and customer relationship management practices on customer satisfaction and customer loyalty. Also, it is aimed to determine whether customer satisfaction has a mediation role in customer loyalty, after-sales support services, and customer relationship management. The research results are essential in determining the level of customer relationship management and after-sales support services that are beneficial in building loyalty in the white goods industry.

\footnotetext{
* Dr. Öğr. Üyesi, Beykent Üniversitesi, Meslek Yüksekokulu, İşletme Yönetimi. Asst. Prof. Dr., Beykent University, Vocational School, Business Management. ORCID 0000-0001-8610-3673

gulsahg@beykent.edu.tr

Cite as/ Atıf: Gençer Çelik, G. (2020). Müşteri memnuniyeti ve müşteri sadakati oluşturmada satış sonrası destek hizmetleri ve müşteri ilişkileri yönetiminin rolü. Turkish Studies - Social, 15(5), 2511-2527. https://dx.doi.org/10.47356/TurkishStudies.44833

Received/Geliş: 02 July/Temmuz 2020

Accepted/Kabul: 20 August/Ağustos 2020

Copyright $($ INTAC LTD, Turkey

Checked by plagiarism software

Published/Yayın: 30 August/Ağustos 2020

CC BY-NC 4.0
} 
Method: The universe of the research consists of customers who need after-sales support services. The private universe of the research comprises customers who bought white goods and used after-sales support services at least once. The sample of the research consists of customers residing in Istanbul. The questionnaire was distributed in June (2020). In determining the sample of the research, the sampling technique was used easily. 95\% confidence interval and 5\% error level were taken as basis in determining the number of samples. 384 sampling limits used by Sekaran (2003) are used. In this research, online survey forms were sent to 600 customers. 521 customers answered the surveys. The responses of 517 participants were found appropriate in terms of analysis. Thus, the number of participants in the research was 517. The information about the scales used in the research is as follows; Scales on after-sales support services and customer relationship management were created by Cronin and Taylor (1994) and adapted by Çelik and Bengül (2008). After-sales support services scale; It consists of warranty services, installation services, and maintenance services. The scale includes ten items. The customer relationship management scale consists of four items. Customer satisfaction scale; Lee (2000), Bolton and Lemon (1999), and Spreng et al. (1996), created and adapted by Çelik and Bengül (2008). The scale consists of four items. The three-item scale created by Chaudhuri (1999) and implemented by Demir (2012) was used to measure customer loyalty. In the response of the items, 5-point Likert scales were used $(1=$ strongly disagree $/ 5=$ strongly agree). SPSS 25 package program and SPSS Process 2.16 macro are used to analyze the data obtained in the research. In the research, a normal distribution assumption test was carried out. The normal distribution hypothesis was examined by the Shapiro - Wilk test and Kolmogorov Smirnov tests. It was observed that normal distribution was not achieved with the obtained results below the $\mathrm{p} \leq 0.050$ level. The skewness and kurtosis values are used to test the normal distribution. It was observed that skewness and kurtosis values were between +1.5 and -1.5. According to Tabachnick and Fidell (2013), and George and Mallery (2010), the normal distribution assumption is provided when the skewness and kurtosis values are between +1.5 and -1.5 .

Conclusion, discussion, and suggestion; As a result of the analysis, it was determined that after-sales support services had a high effect on customer satisfaction and customer loyalty. Also, it has been observed that customer satisfaction has a partially mediating role in after-sales support services in creating customer loyalty. It is possible to state that after-sales support services are a tool of satisfaction and loyalty for customers shopping from the white goods industry. It is concluded that customer relationship management positively affects customer satisfaction and customer loyalty. Also, it is seen that customer satisfaction has a partial mediation role in increasing customer loyalty. According to the results of the research, it can be said that the implementation of customer relations management in the white goods sector is an essential factor in creating customer loyalty and customer satisfaction. When the results of the research and the results in the literature are compared, it is seen that the relationships between variables are similar. Findings on the effect of after-sales support services on customer satisfaction and customer loyalty are similar to the results of the research conducted by Çelik and Bengül (2008), Özgören (2012), Yıldırır (2014) Özgüner and Kurtuldu (2015), Güllülü and Bilgili (2011). The findings regarding the effect of customer relationship management on customer satisfaction and customer loyalty are similar to the results of research conducted by Demirel (2007), Sapura (2018), Ajman and Rehman (2019), Kristian and Panjaitan (2014), Long et al. (2013). The findings obtained in the study can present results in terms of the white goods sector and the province of Istanbul. We recommend that researchers examine how customer loyalty has changed with the Covid-19 pandemic.

Keywords; Customer Relationship Management, After-Sales Support Services, Customer Satisfaction, Customer Loyalty.

Öz: Araştırmanın amacı beyaz eşya sektöründe müşteri ilişkileri yönetimi ve satış sonrası destek hizmetlerinin müşteri memnuniyeti ve müşteri sadakatine etkisinin tespit edilmesidir. Araştırmanın örneklemini satış sonrası destek hizmetlerinden faydalanmış 517 müşteri oluşturmaktadır. Araştırmanın verilerinin toplanmasında anket formları kullanılmıştır. Araştırmada kullanılan anket formu, Beykent Üniversitesi Rektörlüğün 01.06.2020 tarihli etik kurulu kararına göre uygun görülmüştür. Elde edilen verilerin analizi SPSS 25 paket programı ve SPSS Process 2.16 makrosu aracılığı ile gerçekleştirilmiştir. Analizler sonucuna göre satış sonrası destek hizmetlerinin ve müşteri ilişkileri yönetiminin müşteri memnuniyeti ve müşteri sadakatine olumlu yönde etkisi olduğu tespit edilmiştir. Ayrıca, satış sonrası destek hizmetleri ve müşteri ilişkileri yönetiminin müşteri sadakatine etkisinde müşteri memnuniyetinin kısmi arabuluculuk etkisinin olduğu tespit edilmiştir. Araştırma sonuçları genel olarak incelendiğinde; özellikle beyaz eşya sektöründe uygulanacak satış sonrası destek

Turkish Studies - Social, 15(5) 
hizmetlerinin yeterli olarak algılanması ve müşteri ilişkileri yönetiminin uygun şekilde yürütülmesi, müşterilerin memnuniyet düzeylerinin artmasını, buna bağlı olarak da müşteri sadakatinin oluşmasını sağladığını ifade etmek mümkündür. Araştırmada elde edilen bulgular ve alanyazında daha önce elde edilmiş sonuçlar karşılaştırıldığında değişkenler arası ikili ilişkilerin benzerlik gösterdiği görülmektedir. Araştırmada elde edilen bulgular beyaz eşya sektörü ve İstanbul açısından sonuçlar sunabilmektedir. Alanyazındaki araştırmalar incelendiğinde satış sonrası destek hizmetleri, müşteri ilişkileri yönetimi, müşteri memnuniyeti ve müşteri sadakati ilişkilerinin birlikte beyaz eşya sektörü için incelenmediği görülmüştür. Araştırmanın kapsamı ve elde edilen sonuçlar bu açıdan alanyazındaki benzer araştırmalardan farklıdır.

Anahtar Kelimeler: Müşteri İlişkileri Yönetimi, Satış Sonrası Destek Hizmetleri, Müşteri Memnuniyeti, Müşteri Sadakati.

\section{Giriş}

Müşteri kazanımı firmalar için maliyetli bir süreçtir. Reklamlar, tanıtımlar, bilgilendirme çabaları gibi birçok uygulama firmalar için yüklü maliyetler oluşturmaktadır. Bu yüzden müşteri sadakati önemli bir unsur olmaktadır (Eminler vd. 2019). Müş̧eri sadakatini oluşturma için ise müşterinin daha önce bir ürün ya da hizmeti satın almış olması ve bundan memnun kalmış olması gerekmektedir. Müşteri sadakati oluşturma hakkındaki çalışmaların sonuçları bir bütün olarak incelendiğinde, müşteri memnuniyetinin müşteri sadakati için önemli bir yere sahip olduğu görülmektedir. Müşteri memnuniyeti ve sadakatini sağlamak için birçok faaliyet gerçekleştirilmektedir. Müşteri ilişkileri yönetimi ve satış sonrası destek hizmetleri bunlardan ikisidir. Müşteri ilişkileri yönetimi, müşterilerin kazanımını ve yaşam boyu değer elde edilmesine odaklanmaktadır. Böylece bir kişi firmanın müşterisi olduktan sonra onun memnun edilmesi ve sadakatinin gerçekleşmesi için çaba harcanmaktadır (Şimşek, 2017; Eminler vd., 2019). Satış sonrası destek hizmetleri ise müşteriye sunulan ürün ve hizmetlerde yaşanan aksaklıkların giderilmesi için firma tarafından sağlanan destekleri ifade eder. Satış sonrası destek hizmetleri ile müşteriler aldıkları ürün ve hizmetlerden memnuniyet sağlamakta ve firmaya karşı sadakat oluşmaktadır (Sivadas, 2000). Ancak her hizmet ve ürün için aynı sonuç söz konusu olmayabilir. Bu araştırmada satış sonrası destek hizmetleri ve müşteri ilişkileri yönetimi uygulamalarının müşterilerin memnuniyeti ve müşterilerin sadakatinin oluşmasındaki etkisinin tespit edilmesi amaçlanmaktadır. Ayrıca araştırma kapsamında müşteri memnuniyetinin; satış sonrası destek hizmetlerinin ve müşteri ilişkileri yönetiminin müşteri sadakatinde aracılık rolünün olup olmadığının tespit edilmesi amaçlanmaktadır. Araştırmanın amacına uygun olarak beyaz eşya satın almış ve satış sonrası destek hizmetlerine ihtiyaç duymuş müşteriler araştırma kapsamında incelenmektedir. Araştırma, bağımlı değişken, bağımsız değişken ve aracı değişkenin modellenmesi ş̧ekli ile önceki araştırmalardan farklılaşmaktadır. Ayrıca elde edilen bulgular beyaz eşya sektörü açısından genellenebilirdir.

\section{Kavramsal Çerçeve}

Araştırmanın bu kısmında, araştırma kapsamında yer alan kavramların çalışmanın amaçlarına uygun şekilde açıklanması sağlanmaktadır. Bu bölümde satış sonrası destek hizmetleri, müşteri ilişkileri yönetimi, müşteri memnuniyeti ve müşteri sadakati kavramları açıklanmaktadır.

\subsection{Satış Sonrası Hizmetler}

Satış sonrası hizmetler bir ürünün satılması sonrasında müşteriye verilen hizmetlerin tümünün bileşimi olarak tanımlanabilir. Satılan ürünün içeriğine ve türüne bağlı olarak bu hizmetler; garanti hizmetleri, montaj kurulum hizmetleri, servis bakım-onarım hizmetleri, müşteri ilişkileri şeklinde başlıklara ayrılabilmektedir. Söz konusu hizmetler oluşabilecek sorunlarda ürünün kullanılabilmesine devamı sağlamak, ürünün kullanılabilir şekilde son tüketiciye ulaşmasını sağlamak, müşteriye ürünün kullanımı konusunda destek vermek gibi işlevleri yerine getirirler. Satış sonrası hizmetler günümüzde ürünlerin tamamlayıcı parçaları haline gelmişlerdir. Özellikle 
müşterinin algıladığı marka değeri ve markaya duyduğu güveni arttırmakta bununla birlikte de müşteri tatmini ve sadakati üzerinde olumlu etkilerde bulunmaktadır (Çelik ve Bengül, 2008). Alanyazında, zenginleştirilmiş ürün, destekleyici ürün ya da genişletilmiş ürün boyutu olarak adlandırılan ürünün en geniş boyutu; teslim süresi, kurulum, garanti gibi ek fayda ve hizmetleri içermektedir. Günümüz şartlarında çağdaş rekabetin işletmelerin sadece ürettikleri ile değil, ürüne değer katan diğer unsurlar üzerinden olacağı gerçeği ile birlikte satış sonrası hizmetler çok daha önemli hale gelmişlerdir (Cıranoğlu, 2019).

\subsection{Müşteri İlişkileri Yönetimi}

Müşteri ilişkileri yönetimi, müşteri değerinin yaşam boyunca sağlanması, müşterinin tatmin edilmesi ve sadakatinin sağlanması için müşteri ile girişilen stratejik ilişkilerdir. Müşteri ilişkileri yönetimi günümüzde özellikle teknolojik unsurlar vasıtası ile gerçekleştirilmektedir (Bakırtaş, 2013). Ayrıca müşteri ilişkileri yönetiminde müşterinin farklı özellikleri göz önüne alınarak özelleştirilmiş ilişkiler kullanılmaktadır (Doğan vd. 2018). Müşteri ilişkileri yönetiminin ortaya çıkmasına neden olan faktörler; geleneksel pazarlama yaklaşımının pahalı olması, müşteri payının pazar payından daha önemli olması, müşteri sadakatini sağlaması, eldeki müşterinin yeni müşteriye göre daha az maliyetli olması gibi faktörlerdir. Öyle ki müşteri şirketler için en önemli paydaş olarak görülür ve faaliyetler müşteri çevresinde oluşturulur (Demir ve Kırdar, 2007).

\subsection{Müşteri Memnuniyeti}

İnsanlar hazcı yapıları sebebi ile zevki arar ve acıdan kaçınma eğiliminde olurlar. Bu açıdan bakıldığında insanların yaptıkları her faaliyet memnuniyet odaklıdır ve alışveriş buna bir istisna değildir (Paul vd., 2016). Pazarlama alanında memnuniyet tipik olarak bir markanın genel performansının bir ölçüsü olarak kullanılmaktadır. Aynı zamanda memnuniyet işletmenin performansının yeterliliğini açıklamak için de kullanılabilmektedir. Memnuniyet, bilişsel, duyuşsal ve göreceli bir yarg1, yani öznel bir deneyim ile önceki bir standart arasındaki karşılaştırmanın sonucu olarak kabul edilmektedir (Rivera vd, 2016). Müş̧eri memnuniyeti, ürün veya hizmetin performans beklentilerini aştığında itici güçtür. Müşteri memnuniyeti, ürün ya da hizmetin deneyimlenmesinden sonra ne kadar beğenildiğini veya beğenmediğini yansitan ve tüketicinin zihninde oluşan algıdır. Mevcut literatürde, müşteri memnuniyetinin iki kavramsallaştırması söz konusudur: (a) işleme özgü memnuniyet ve (b) kümülatif memnuniyet. İşleme özgü memnuniyet, tek bir satın alma işleminden kaynaklanan ürün veya hizmet kullanımıyken; kümülatif memnuniyet birkaç satın alımdan sonra bir ürün veya hizmetten genel memnuniyet ve zaman içindeki deneyimleri ile ilgilidir. Olumlu kümülatif memnuniyet müşteri sadakatine yol açabilmektedir. Müşteri memnuniyeti üç açıdan önemlidir; müşterinin sadakati, tavsiyesi ve tekrar satın almasına yol açması (Meesala ve Paul, 2018).

\subsection{Müşteri Sadakati}

Tanım olarak, sadakat, gelecekte belirli bir ürün veya hizmeti sürekli olarak yeniden satın almak veya yeniden kullanmak için derinden hissedilen bir taahhüttür. Aynı markanın tekrar tekrar tüketilmesine neden olmaktadır. Müşteri sadakati, muhtemelen herhangi bir kuruluştaki en iyi başarı ölçülerinden biridir. Dolayısıyla, müşteri sadakatinin geliştirilmesi, sürdürülmesi ve güçlendirilmesi, firmaların pazarlama faaliyetlerinin çoğunun odak noktası olmaya devam etmektedir (Nyadzayo ve Khajehzadeh, 2016). Alanyazında davranışsal ve tutumsal olmak üzere iki tür sadakatten bahsedilmektedir. Davranışsal açıdan, sadakat bir davranış biçimidir. Tekrarlanan satın alma sadakat göstergesi olarak kabul edilmektedir. Tutumsal yaklaşım açısından sadakat ise kişisel bir tutumu ifade etmektedir. Farklı duyguların müşterilerin bir ürüne, hizmete veya perakendeciye olan bağlılığını oluşturması nedeniyle kişisel bir tutumu işaret etmektedir. Tutum sadakati söz konusu olduğunda müşteriler satın alma işlemini tekrarlamasalar da tedarikçilerinin hizmetlerini diğer müşterilere tavsiye etmektedirler (Silva vd., 2016). Alanyazında yapılan birçok çalışmada müşteri 
memnuniyeti ve müşteri sadakati arasında bağlantı olduğunu ortaya koymuştur. (Kasiria vd., 2017; Chen, 2012; Kumar vd., 2013; Suh ve Yi, 2006).

\subsection{Kavramsal İlişkiler ve Hipotez Geliştirme}

Çelik ve Bengül (2008) tarafından yapılan araștırmada satıș sonrası hizmetlerin müșterinin tatmini, sadakati ve memnuniyeti üzerindeki etkisinin tespit edilebilmesi amaçlanmıştır. Araştırmanın örneklemini satış sonrası destek hizmetlerinden faydalanmış 103 birey oluşturmaktadır. Araştırma sonucunda satış sonrası hizmetlerinin müşteri memnuniyeti açısından anlamlı etkisinin olduğu, marka sadakati açısından ise dolaylı bir etkisinin olduğu sonucuna ulaşılmıştır.

Özgören (2012) tarafından yapılan araştırmada satış sonrası hizmetlerin müşterilerin sadakatine etkisinin tespit edilmesi amaçlanmıştır. Araştırmada Sonny Ericsson örnek olay incelemesi yapılmıştır. Araştırma nitel tekniklerle gerçekleştirilmiştir. Satış sonrası hizmetlerin müşterinin sadakati açısından önemli bir faktör olduğu, müşterilerin yeniden satın alma işlemi gerçekleştirmesi için satış sonrası hizmetlerin hayati önem taşıdığı vurgusu yapılmıştır.

Yıldırır (2014) tarafindan yapılan araştırmada satış öncesi ve sonrası destek hizmetlerinin müşterilerin sadakatini ne şekilde etkilediğinin tespit edilmesi amaçlanmıştır. Araştırmada 478 katılımcı ile anket çalışması yapılmıştır. Araştırmanın örneklemi 3 farklı şehirdeki otomobil kullanıcısıdır. Araştırma sonuçları incelendiğinde satış sonrası destek hizmetlerinin satış öncesi hizmetlere göre sadakat üzerinde daha yüksek etkisinin olduğu sonucuna ulaşılmıştır.

\section{$H_{1}$ : Satış sonrası destek hizmetleri müş̧teri sadakatini arttırmaktadır.}

Özgüner ve Kurtuldu (2015) tarafindan yapılmış olan çalışmada yetkili sevişlerde sağlanan satış sonrası hizmetlerinin müşterilerin memnuniyeti ile olan ilişkisinin tespit edilmesi amaçlanmıştır. Araştırmanın örneklemi İstanbul ilindeki 929 araba sahibidir. Araştırma sonucunda araç sahiplerinin demografik özelliklerinin müşteri memnuniyeti ve satış sonrası destek hizmetlerini algılamada önemli unsurlar olduğu görülmüsstür. Satış sonrası destek hizmetleri ile müşteri memnuniyeti arasında yüksek düzeyde olumlu yönde ilişkiler tespit edilmiştir.

Tüzüntürk vd. (2016) tarafından yapılan araştırmada otomobil sektöründe satış sonrası hizmetlerin müşterilerin memnuniyetleri üzerine etkisinin tespit edilmesi amaçlanmıştır. Araştırmada Bursa ilindeki 342 müşteri ile anket çalışması gerçekleştirilmiştir. Araştırma sonucunda müşteri memnuniyetinin müşteri sadakatini olumlu yönde etkilediği sonucuna ulaşılmıştır.

Güllülü ve Bilgili (2011) tarafından yapılan araştırmada satış sonrası destek hizmetlerinde satış sonrası hizmetlerin müşterilerin memnuniyeti ve kalite algısı ile olan ilişkilerin tespit edilmesi amaçlanmıştır. Araştırmada Erzurum ilinde satış sonrası desteklerden faydalanan 388 katılımcı ile anket çalışması yapılmıştır. Araştırma sonucunda satış sonrası hizmetlerin teknik ve fonksiyonel kalitesinin müşteri memnuniyetine olumlu yönde etkisinin olduğu sonucuna ulaşılmıştır.

\section{$\mathrm{H}_{2}$ : Satış sonrası destek hizmetleri müşsteri memnuniyetini arttırmaktadır.}

Demirel (2007) tarafından yapılan araştırmanının amacı bankacılık sektöründe müşteri iliş̧kileri yönetimi uygulamalarının müşteri sadakatini nasıl etkilediğinin tespit edilmesidir. Araştırmanın örneklemi 395 banka çalışanıdır. Araştırma sonucunda müşteri ilişkileri yönetimi uygulamalarının müşterilerin sadakatini olumlu yönde arttırdığg sonucuna ulaşılmıştır. Özellikle müşteriye verilen değer, müşteri ile etkileşim, verilere bağlı oluşturulan hizmetler ve verilerin uygulamalarda kullanımı müşterilerin sadakatini olumlu yönde arttırmaktadır.

Sapura (2018) tarafından yapılan araştırmada müşteri ilişkileri yönetimi uygulamalarının ve müşteri memnuniyetinin müşteri sadakatine etkisinin tespit edilmesi amaçlanmıştır. Araştırmada 500 banka müşterisi ile anket çalışması yapılmıştır. Araştırma sonucunda müşteri ilişkileri yönetiminin 
müşteri memnuniyetini arttırdığı, müşteri memnuniyetinin de müşteri sadakatini arttırdığı sonucuna ulaşılmıştır. Ayrica müşteri ilişkileri yönetiminin müşteri sadakati üzerinde direk etkisinin olduğu sonucuna ulaşı1mıştır.

Ajmal ve Rehman (2019) tarafından yapılan araştırmada bankacılık sektöründe müşteri ilişkileri yönetiminin müşterinin sadakatine etkisinin tespit edilmesi amaçlanmıştır. Araştırmanın örneklemini 302 banka müşterisi oluşturmaktadır. Araştırma Pakistan'da gerçekleştirilmiştir. Araştırma sonuçlarına göre müşteri ilişkileri yönetimi uygulamalarının müşteri sadakatini olumlu yönde etkilediği sonucuna ulaşılmıştır.

\section{$\mathrm{H}_{3}$ : Müşteri ilişsileri yönetimi uygulamaları müşteri sadakatini arttırmaktadır.}

Kristian ve Panjaitan (2014) tarafından yapılan araştırmada kaliteli hizmet, müşteri ilişkileri yönetimi, müşteri memnuniyeti ve müşteri sadakati arasındaki ilişkilerin tespit edilmesi amaçlanmıştır. Araştırma Endonezya'daki 200 katılımcı ile gerçekleştirilmiştir. Araştırma yemeiçme alanında faaliyet gösteren bir işletmenin müşterileri ile gerçekleştirilmiştir. Araştırma sonucunda müşteri ilişkileri yönetiminin müşteri memnuniyeti üzerinde, müşteri ilişkileri yönetiminin müşteri sadakati üzerinde, müşteri memnuniyetinin müşteri sadakati üzerinde etkisi olduğu tespit edilmiştir.

Long vd. (2013) tarafından yapılan araştırmada müşteri ilişkileri yönetiminin müşteri tatmini ve müşteri sadakatine etkisinin tespit edilmesi amaçlanmıştır. Araştırma İran'daki 300 katılımcı ile gerçekleştirilmiştir. Araştırma sonucunda personellerle müşterilerin ilişkilerinin müşteri sadakati ve müşteri memnuniyetini sağlamada önemli bir unsur olduğu sonucuna ulaşılmıştır.

Sofi vd. (2020) tarafından yapılan araştırmada konaklama sektöründeki müşteri ilişkileri yönetimi uygulamalarının müşteri memnuniyetine etkisinin tespit edilmesi amaçlanmıştır. Araştırmada 176 katılımcıdan anket formaları aracılığı ile yanıt toplanmıştır. Verilerin analizi sonucunda, müşteri ilişkileri yönetiminin müşteri memnuniyetini olumlu yönde arttırdığı sonucuna ulaşılmıştır.

\section{$H_{4}$ : Müşteri ilişkileri yönetimi uygulamaları müşsteri memnuniyetini arttırmaktadır.}

Yukarıda yer alan çalışma sonuçlarına göre müşteri ilişkileri yönetimi ve satış sonrası destek hizmetlerinin müşteri sadakatini arttırmasında müşteri memnuniyetinin önemli bir unsur olduğu çıkarımını yapmak mümkündür. Bu çıkarımdan hareketle satış sonrası destek hizmetleri ve müşteri ilişkileri yönetimini uygulamalarının müşteri sadakatine etkisinde müşteri memnuniyetinin rolünün hipotezleri şu şekilde oluşturulmuştur;

$H_{5}$ : Satış sonrası destek hizmetlerinin müsşteri sadakatine etkisinde müşsteri memnuniyetinin arabuluculuk rolï bulunmaktadır.

\section{H: Müşsteri ilişkileri yönetiminin müşteri sadakatine etkisinde müşteri memnuniyetinin arabuluculuk rolï bulunmaktadır.}

\section{Araştırmanın Metodolojisi}

Araştırmanın bu aşamasında, araştırmanın hangi amaçlar yapıldığı, veri toplama araçları ve analiz teknikleri, araştırmanın evreni ve örneklemi ile araştırmanın kavramsal modeli hakkında bilgiler verilmektedir.

\subsection{Araştırmanın Amacı ve Önemi}

Firmalar arasındaki rekabetin sertliği düşünüldüğünde yeni müşteri kazanmanın zorluğu açıkça fark edilmektedir. Firmalar için yeni müşteri kazanımı oldukça maliyetli ve uğraş gerektiren bir konudur. Ancak kazanılmış müşteriden yaşam boyu değer elde etmek yeni müşteri kazanmaktan daha uygun bir seçenek olarak görülebilmektedir. Müşteri yönetimi uygulamaları müşterilerinden 
yaşam boyu değer elde etme niyeti ile yapılan faaliyetleri kapsamaktadır. Böylece müşterinin rakipleri tercih etmesinin engelleneceği ve kişiselleştirilmiş hizmetlerle müşterinin tatmininin ve sadakatinin sağlanacağı düşünülmektedir. Ayrıca firmayı en az bir kez tercih etmiş ve alınan hizmet ve ürünlerin kullanımında satış sonrası destek hizmetlerine ihtiyaç duymuş müşterilerin tatmin edilmesi de müşterinin sadakati açısından önem taşımaktadır. Bu yüzden satış sonrası destek hizmetleri firma hakkında daha olumlu algılar oluşturabilmektedir. Araştırmada satış sonrası destek hizmetleri ve müşteri ilişkileri yönetimi uygulamalarının müşterilerin memnuniyeti ve müşterilerin sadakatinin oluşmasındaki etkisinin tespit edilmesi amaçlanmaktadır. Ayrıca araştırma kapsamında müşteri memnuniyetinin; satış sonrası destek hizmetlerinin ve müşteri ilişkileri yönetiminin müşteri sadakatinde aracılık rolünün olup olmadığının tespit edilmesi amaçlanmaktadır. Elde edilecek sonuçlar beyaz eşya sektöründe müşteri ilişkileri yönetimi ve satış sonrası destek hizmetlerinin sadakat oluşturmada ne düzeyde faydalı olduğunu tespit etme açısından önemlidir.

\subsection{Araştırmanın Evreni ve Örneklemi}

Araştırmanın evreni satış sonrası destek hizmetlerine ihtiyaç duyan müşterilerden oluşmaktadır. Araştırmanın özel evreni ise beyaz eşya satın almış ve sonrasında satış sonrası destek hizmetlerini en az bir kez kullanmış olan müşterilerden oluşturmaktadır. Araştırmanın örneklemini İstanbul'da ikamet eden müşteriler oluşturmaktadır. Anket formunun dağıtılması işlemi Haziran (2020)'da gerçekleştirilmiştir. Araştırmanın örnekleminin belirlenmesinde kolayda örneklem tekniği kullanılmıştır. Örneklem sayısının belirlenmesinde \%95 güven aralığı ve $\% 5$ hata payı esas alınmıştır. Sınırsız veya sayılamayan örneklemler için Sekaran (2003)'ın uygun gördüğü 384 örneklem sınırı kullanılmaktadır. Bu araştırmada 600 müşteriye online anket formu gönderilmiştir. Anket formunu dolduran 521 müşteriden 517'sinin verdikleri yanıtlar analizler açısından uygun bulunmuştur. Böylece araştırmanın katılımcı sayısı 517 olarak gerçekleşmiştir.

\subsection{Araştırmanın Veri Toplama Araçları ve Analiz Teknikleri}

Araştırmada veri toplamada anket formu kullanılmıştır. Araştırmada kullanılan anket formu, Beykent Üniversitesi Rektörlüğün 01.06.2020 tarihli etik kurulu kararına göre uygun görülmüştür. Anket formu içerisinde iki bölüm yer almaktadır. Kısımda katılımcıların demografik özelliklerinin ölçülmesinde kullanılan dokuz madde bulunmaktadır. İkinci bölümde satış sonrası destek hizmetleri, müşteri ilişkileri yönetimi, müşteri memnuniyeti ve müşteri sadakati hakkında sorular yer almaktadır. Satış sonrası destek hizmetleri ve müşteri ilişkileri yönetimi hakkındaki ölçekler Cronin ve Taylor (1994) tarafından oluşturulmuş ve Çelik ve Bengül (2008) tarafindan uyarlanmıştır. Satış sonrası destek hizmetleri; garanti hizmetleri, montaj hizmetleri ve bakım hizmetleri boyutlarından oluşmaktadır. Ölçekte 10 madde yer almaktadır. Müşteri ilişkileri yönetimi ölçeği ise dört maddeden oluşmaktadır. Lee (2000), Bolton ve Lemon (1999) ve Spreng vd. (1996) tarafindan oluşturulup, Çelik ve Bengül (2008) tarafindan uyarlanan müşteri memnuniyeti ölçeği ise dört maddeden oluşmaktadır. Müşteri sadakatinin ölçülmesinde Chaudhuri (1999) tarafindan oluşturulan ve Demir (2012) tarafından uygulanan üç maddelik ölçek kullanılmıştır. Maddelerin yanıtlanmasında 5'li likert tipinde ölçekler kullanılmıştır ( $1=$ kesinlikle katılmıyorum $/ 5=$ kesinlikle katılıyorum). Araştırmada elde edilen verilerin analizinde SPSS 25 paket programı ve SPSS Process 2.16 makrosu kullanılmaktadır. Araştırma kapsamında öncelikle faktör ve güvenilirlik analizleri yapılmaktadır. Sonrasında katılımcıların tanımlayıcı özellikleri hakkında bilgiler verilmektedir. Korelasyon analizi ile değişkenler arasındaki ilişkiler incelenmekte ve daha sonrasında da SPSS Process makrosu ile değişkenlerin nedensellik ilişkileri hakkında bulgular elde edilmektedir. 


\subsection{Araştırmanın Modeli}

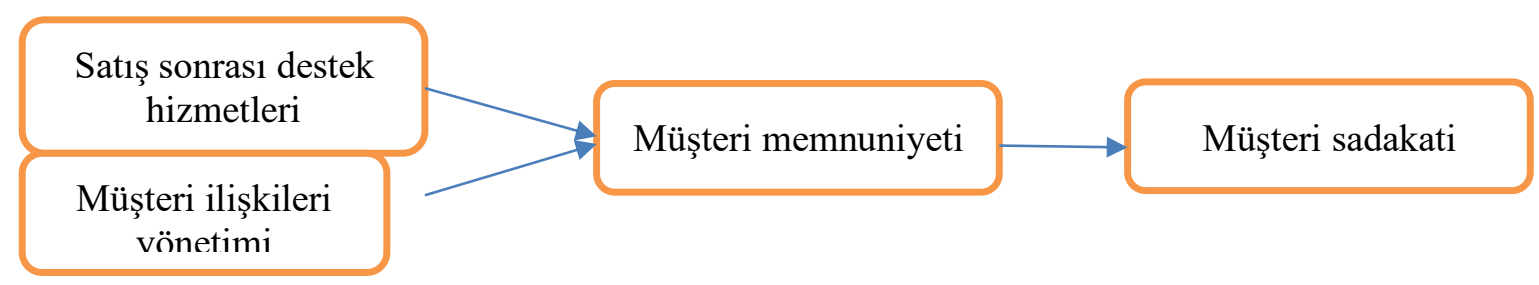

Şekil 1. Araştırmanın kavramsal modeli

Araştırmanın kavramsal modeli (Şekil 1) incelendiğinde satış sonrası destek hizmetleri ve müşteri ilişkileri yönetiminin bağımsız değişken, müşteri memnuniyetinin aracı/arabulucu değişkeni, müşteri sadakatinin ise bağımlı değişkeni temsil ettiği görülmektedir.

\section{Araştırmanın Bulguları}

Araştırmanın bu kısmında faktör analizi, güvenilirlik analizi, tanımlayıcı istatistikler, korelasyon analizi ve regresyona analizi sonuçları yer almaktadır. Araştırmada normal dağılım varsayımı testi gerçekleştirilmiştir. Shapiro-Wilk testi ve Kolmogorov-Smirnov testleri ile normal dağ 1 lım varsayımı incelenmiştir. Elde edilen sonuçların $p \leq 0,050$ düzeyinin altında olması ile normal dağılımın sağlanmadığı görülmüştür. Normal dağılım diğer bir inceleme metodu olan çarpıklık ve basıklık değerlerinin $+1,5$ ile $-1,5$ arasında dağıldığı görülmüştür. Tabachnick ve Fidell (2013) ile George ve Mallery (2010) çarpıklık ve basıklık değerlerinin +1,5 ile -1,5 arasında olması durumunda normal dağılımın varsayılabileceğini ifade etmektedir.

\section{Faktör Analizi Sonuçları}

Tablo 1: Faktör Analizi Sonuçları

\begin{tabular}{cccccc}
\hline Ölçek & $\begin{array}{c}\text { Kaiser-Meyer- } \\
\text { Olkin Örneklem } \\
\text { Yeterliliği } \\
\text { Ölçümü }\end{array}$ & $\begin{array}{c}\text { Bartlett's } \\
\text { Küresellik Testi, Yaklaşık Ki-Kare } \\
\text { Anlamlılık }\end{array}$ & $\begin{array}{c}\text { Serbestlik } \\
\text { Derecesi }\end{array}$ & $\begin{array}{c}\text { Açılanan } \\
\text { Varyans }\end{array}$ \\
\hline $\begin{array}{c}\text { Satış Sonrası } \\
\text { Destek } \\
\text { Hizmetleri }\end{array}$ &, 927 & 0,000 & 3083,869 & 45 & 59,248 \\
\hline $\begin{array}{c}\text { Garanti } \\
\text { Hizmetleri }\end{array}$ &, 736 & 0,000 & 732,612 & 3 & 78,638 \\
\hline $\begin{array}{c}\text { Montaj } \\
\text { Hizmetleri }\end{array}$ &, 705 & 0,000 & 596,027 & 3 & 74,565 \\
\hline $\begin{array}{c}\text { Bakım } \\
\text { Hizmetleri }\end{array}$ &, 819 & 0,000 & 823,318 & 6 & 68,420 \\
\hline $\begin{array}{c}\text { Müşteri İliskkileri } \\
\text { Yönetimi }\end{array}$ &, 817 & 0,000 & 1034,636 & 6 & 72,735 \\
\hline $\begin{array}{c}\text { Müşsteri } \\
\text { Memnuniyeti }\end{array}$ &, 832 & 0,000 & 1032,183 & 6 & 72,812 \\
\hline Müşteri Sadakati &, 734 & 0,000 & 697,468 & 3 & 77,823 \\
\hline
\end{tabular}

Araştırmada kullanılan ölçüm araçlarının faktör analizi sonuçları Tablo 1'de yer almaktadır. Elde edilen bulguların değerlendirilmesinde Hair vd. (2014) faktör analizi sonuçları (KMO değeri $\geq 0,600$, Bartlett's küresellik testi $\leq 0,050$, açıklanan toplam varyans $\geq \% 60$ ) hakkındaki açıklamaları göz önüne alınmaktadır. Satış sonrası destek hizmetlerinin KMO değeri 0,927, Bartlett's küresellik testi sonucu $0,000 \leq 0,050$ düzeyinde anlamlı ve açılanan toplam varyansı ise $\% 59,2$ 'dir. Garanti hizmetleri ölçeğinin KMO değeri 0,736, Bartlett's küresellik testi $0,000 \leq 0,050$ düzeyinde anlamlı ve 
açıklanan toplam varyansı ise \%78,6'dır. Montaj hizmetleri ölçeğinin KMO değeri 0,705, Bartlett's küresellik testi $0,000 \leq 0,050$ düzeyinde anlamlı ve açıklanan toplam varyansı ise $\% 74,5$ 'tir. Bakım hizmetleri ölçeğinin KMO değeri 0,816, Bartlett's küresellik testi $0,000 \leq 0,050$ düzeyinde anlamlı ve açılanan toplam varyansı ise $\% 68,4$ olarak tespit edilmiştir. Müşteri ilişkileri yönetimi ölçeğinin KMO değeri 0,817, Bartlett's küresellik testi $0,000 \leq 0,050$ ve açıklanan toplam varyansı ise $\% 72,7$ olarak tespit edilmiştir. Müşteri memnuniyeti ölçeğinin KMO değeri 0,832, Bartlett's küresellik testi $0,000 \leq 0,050$ düzeyinde anlamlı ve açıklana toplam varyans $1 \% 72,8$ olarak tespit edilmiştir. Müşteri sadakati ölçeğinin KMO değeri 0,734 , Bartlett's küresellik testi $0,000 \leq 0,050$ ve açılanan toplam varyans1 \%77,8'dir. Faktör analizi sonucunda elde edilen değerler göz önüne alındığında ölçüm araçlarının KMO değerinin yeterli düzeyde olduğunu ifade etmek mümkündür. Ayrıca ölçüm araçlarının ölçtükleri olguları açıklama oranı yeterli düzeydedir.

\section{Güvenilirlik Analizi Sonuçları}

Tablo 2: Güvenilirlik Analizi Sonuçları

\begin{tabular}{|c|c|c|c|}
\hline Ölçek & Madde & $\begin{array}{l}\text { Madde Silindiğinde } \\
\text { Cronbach's Alpha }\end{array}$ & $\begin{array}{c}\text { Cronbach's } \\
\text { Alpha Katsayıs1 }\end{array}$ \\
\hline \multicolumn{3}{|c|}{ Satış sonrası destek hizmetleri } &, 923 \\
\hline \multirow{3}{*}{ Garanti } & garanti1 & ,816 & \multirow{3}{*}{,864 } \\
\hline & garanti2 & ,790 & \\
\hline & garanti3 &, 820 & \\
\hline \multirow{3}{*}{ Montaj } & montaj1 & ,787 & \multirow{3}{*}{,827 } \\
\hline & montaj2 & ,706 & \\
\hline & montaj3 &, 792 & \\
\hline \multirow{4}{*}{ Bakım } & bakım1 & ,808 & \multirow{4}{*}{,846 } \\
\hline & bakım2 & ,790 & \\
\hline & bakım3 & 811 & \\
\hline & bakım4 & ,809 & \\
\hline \multirow{4}{*}{$\begin{array}{l}\text { Müşteri } \\
\text { ilişkileri } \\
\text { yönetimi }\end{array}$} & müşteriilişkileri1 & ,844 & \multirow{4}{*}{,875 } \\
\hline & müşteriilişkileri2 & ,847 & \\
\hline & müşteriilişkileri3 & 840 & \\
\hline & müşteriilişkileri4 & ,828 & \\
\hline \multirow{4}{*}{$\begin{array}{c}\text { Müşteri } \\
\text { memnuniyeti }\end{array}$} & müşterimemnuniyetil &, 830 & \multirow{4}{*}{,875 } \\
\hline & müşterimemnuniyeti2 & ,826 & \\
\hline & müşterimemnuniyeti3 & ,848 & \\
\hline & müşterimemnuniyeti4 & ,853 & \\
\hline \multirow{3}{*}{ Sadakat } & sadakat1 & ,801 & \multirow{3}{*}{, 857} \\
\hline & sadakat2 & ,788 & \\
\hline & sadakat3 & 811 & \\
\hline
\end{tabular}

Güvenilirlik analizi sonuçlanı Tablo 2'de yer almaktadır. Güvenilirlik analizinin gerçekleştirilmesinde Cronbach's Alpha katsayısı kullanılmıştır. Hair vd. (2014)'e göre Cronbach's Alpha katsayısını 0,600 üzerinde olması, daha önce uygulanmış ölçekler için ise 0,700 üzerinde olması ölçeğin güvenilirliğini göstermektedir. Satış sonrası destek hizmetleri ölçeğinin Cronbach's Alpha katsayıs1 0,923, garanti hizmetleri ölçeğinin Cronbach's Alpha katsayısı 0,864, montaj hizmetleri ölçeğinin Cronbach's Alpha katsayısı 0,827, bakım hizmetleri ölçeğinin Cronbach's Alpha katsayısı 0,846, müşteri ilişkileri yönetimi ölçeğinin Cronbach's Alpha katsayısı 0,875, müşteri memnuniyeti ölçeğinin Cronbach's Alpha katsayıs1 0,875 ve müşteri sadakati ölçeğinin Cronbach's Alpha katsayısı ise 0,857 olarak tespit edilmiştir. Ölçeklerin tamamının yüksek düzeyde güvenilirlik katsayısına sahip olduğunu ifade etmek mümkündür. Faktör analizi ve güvenilirlik analizi esnasında herhangi bir madde araştırma kapsamından çıkarılmamıştır. 
Tablo 3: Tanımlayıcı İstatistikler

\begin{tabular}{|c|c|c|c|c|c|c|c|}
\hline & & $\mathrm{N}$ & $\%$ & & & $\mathrm{~N}$ & $\%$ \\
\hline \multirow{3}{*}{ Cinsiyet } & Kadın & 137 & 26,5 & \multirow{4}{*}{ Medeni Durum } & Bekar & 243 & 47,0 \\
\hline & Erkek & 380 & 73,5 & & Evli & 274 & 53,0 \\
\hline & Toplam & 517 & 100,0 & & & & 1000 \\
\hline \multirow{6}{*}{ Yaş } & $18-25$ & 33 & 6,4 & & Toplam & 517 & 100,0 \\
\hline & $26-33$ & 98 & 19,0 & \multirow{6}{*}{ Eğitim Düzeyi } & İlköğretim & 41 & 7,9 \\
\hline & $34-41$ & 190 & 36,8 & & Lise & 151 & 29,2 \\
\hline & $42-59$ & 147 & 28,4 & & Önlisans & 149 & 28,8 \\
\hline & 60 & 47 & 9,1 & & Lisans & 132 & 25,5 \\
\hline & Toplam & 517 & 100,0 & & Lisansüstü & 44 & 8,6 \\
\hline \multirow{6}{*}{ Çocuk Sayısı } & Yok & 201 & 38,9 & & Toplam & 517 & 100,0 \\
\hline & 1 & 82 & 15,9 & \multirow{6}{*}{ Gelir Düzeyi } & $0-2500$ & 51 & 9,9 \\
\hline & 2 & 126 & 24,4 & & $2501-4000$ & 137 & 26,5 \\
\hline & 3 & 83 & 16,1 & & $4001-6000$ & 174 & 33,7 \\
\hline & 4 Ve Üzeri & 25 & 4,8 & & $6001-7500$ & 108 & 20,9 \\
\hline & Toplam & 517 & 100,0 & & 75001 & 47 & 9,1 \\
\hline \multirow{4}{*}{ Şikayet } & Evet & 246 & 47,6 & & Toplam & 517 & 100,0 \\
\hline & Hayır & 267 & 51,6 & \multirow{3}{*}{ Müşteri Türü } & Bireysel & 330 & 63,8 \\
\hline & Yanitsiz & 4 &, 8 & & Kurumsal & 187 & 36,2 \\
\hline & Toplam & 517 & 100,0 & & Toplam & 517 & 100,0 \\
\hline
\end{tabular}

Araştırmaya katılan müşterilerin tanımlayıcı özellikleri ile ilgili bilgiler Tablo 3'te yer almaktadır. Katılımcıların \%26,5'i kadınlar, \%73,5'i ise erkeklerden oluşmaktadır. Katılımcılarının $\% 30,4$ 'ü bekar, \%53'ü evli ve \%16,6'sı ise evlenip ayrılmıș bireylerden oluşmaktadır. Katılımcıların $\% 6,4$ 'ü 18- 25 yaş aralığında, \%19'u 26,33 yaş aralığında, \%36,8'i 34-41 yaş aralığında, \%28,4'ü 42-59 yaş aralığında ve $\% 9,1$ 'i ise 60 yaş ve üzerindeki kişilerden oluşmaktadır. Katılımcıların \%7,9'u ilköğretim, \%29,2'si lise, \%28,8'i önlisans, \%25,5'i lisans, 8,6's lisansüstü düzeyinde eğitim düzeyine sahiptir. Kat1lımlarının \%38,9'unun çocuğu bulunmazken, \%15,9'unun bir çocuğu, $\% 24,4$ 'ünün iki çocuğu, \%16,1'inin üç çocuğu, \%4,8'inin ise 4 ve daha fazla sayıda çocuğu bulunmaktadır. gelir düzeyleri incelendiğinde, katılımcıların \%9,9'u 2500 TL ve altında, \%26,5'i 2501-4000 TL arasinda, \%33,7'si 4001-6000 TL arasinda, \%20,9'u 6001-7500 TL arasinda, \%9,1'i ise $7501 \mathrm{TL}$ ve üzerinde gelir düzeyine sahiptir. Müşterilerin aldıkları hizmetler hakkında oluşturdukları şikayetler incelendiğinde, katılımcıların \%47,6'sı şikayette bulunduğunu belirtirken, \%51,6'sı şikayette bulunmadığını ifade etmiştir. Katılımcıların müşteri kategorisi incelendiğinde, müşterilerin \%63,8'inin bireysel, \%36,2'si ise kurumsal müşterilerden oluştuğu görülmektedir. 
Tablo 4: Korelasyon Analizi Sonuçları

\begin{tabular}{|c|c|c|c|c|c|c|c|}
\hline & $\begin{array}{c}\text { Garanti } \\
\text { Hizmetleri }\end{array}$ & $\begin{array}{l}\text { Montaj } \\
\text { Hizmetleri }\end{array}$ & $\begin{array}{c}\text { Bakım } \\
\text { Hizmetleri }\end{array}$ & $\begin{array}{c}\text { Satış } \\
\text { Sonrası } \\
\text { Destek } \\
\text { Hizmetleri }\end{array}$ & $\begin{array}{l}\text { Müșteri } \\
\text { İlişkileri } \\
\text { Yönetimi }\end{array}$ & $\begin{array}{c}\text { Müşteri } \\
\text { Memnuniyeti }\end{array}$ & $\begin{array}{l}\text { Müşteri } \\
\text { Sadakati }\end{array}$ \\
\hline $\begin{array}{cc}\text { Garanti } & \text { Pearson } \\
\text { hizmetleri } & \text { Korelasyon } \\
\end{array}$ & 1 & & & & & & \\
\hline $\begin{array}{cc}\text { Montaj } & \text { Pearson } \\
\text { hizmetleri } & \text { Korelasyon }\end{array}$ &, $715^{* *}$ & 1 & & & & & \\
\hline $\begin{array}{cc}\text { Bakım } & \text { Pearson } \\
\text { hizmetleri } & \text { Korelasyon }\end{array}$ &, $670^{* * *}$ &, $749^{* * *}$ & 1 & & & & \\
\hline $\begin{array}{cc}\text { Satış sonrası } & \text { Pearson } \\
\text { destek } & \text { Korelasyon } \\
\text { hizmetleri } & \\
\end{array}$ &, $878^{* *}$ &, $906^{* * *}$ & ,910** & 1 & & & \\
\hline $\begin{array}{cc}\text { Müssteri } & \text { Pearson } \\
\text { ilişkileri } & \text { Korelasyon } \\
\text { yönetimi } & \end{array}$ &, $650^{* * *}$ &, $665^{* * *}$ &, $750^{* *}$ &, $770^{* * *}$ & 1 & & \\
\hline $\begin{array}{cc}\text { Müşteri } & \text { Pearson } \\
\text { memnuniyeti } & \text { Korelasyon }\end{array}$ & ,629** &, $669^{* *}$ &, $736^{* *}$ &, $758^{* *}$ &, $832^{* *}$ & 1 & \\
\hline $\begin{array}{cc}\text { Müssteri } & \text { Pearson } \\
\text { sadakati } & \text { Korelasyon } \\
\end{array}$ &, $611^{* *}$ &, $674^{* * *}$ &, $709^{* *}$ &, $742^{* *}$ &, $789^{* *}$ &, $834^{* *}$ & 1 \\
\hline
\end{tabular}

Değişkenler arası ilişkilerin tespit edilebilmesi amacıyla yapılan korelasyon analizi sonuçları Tablo 4'te yer almaktadır. Garanti hizmetleri ile müssteri memnuniyet arasında orta düzeyde ve pozitif yönde, garanti hizmetleri ile müşteri sadakati arasında orta düzeyde ve pozitif yönde anlamlı ilişki tespit edilmiştir. Montaj hizmetleri ile müşteri memnuniyeti arasında orta düzeyde ve pozitif yönde, montaj hizmetleri ile müşteri sadakati arasında orta düzeyde ve pozitif yönde anlamlı ilişki tespit edilmiştir. Bakım hizmetleri ile müşteri memnuniyeti arasında yüksek düzeyde ve pozitif yönde, bakım hizmetleri ile müş̧eri sadakati arasında ise yüksek düzeyde ve pozitif yönlü anlamlı ilişki tespit edilmiştir. Satı̧s sonrası destek hizmetlerinin müşteri ilişkileri yönetimi, müşteri memnuniyeti ve müşteri sadakati ile arasında yüksek düzeyde, pozitif yönde anlamlı ilişkiler tespit edilmiştir. Müşteri ilişkileri yönetimi uygulamaları ile müşteri memnuniyeti arasında yüksek düzeyde ve pozitif yönde, müşteri ilişkileri yönetimi uygulamaları ile müşteri sadakati arasında yüksek düzeyde ve pozitif yönde anlamlı ilişki tespit edilmiştir. Müşteri memnuniyeti ile müşteri sadakati arasında yüksek düzeyde ve pozitif yönde anlamlı ilişki tespit edilmiştir. Elde edilen ilişkiler $\mathrm{p} \leq 0,010$ düzeyinde istatistiki olarak anlamlıdır. Değişkenler arasındaki ilişkilerin istatistiki açıdan anlamlı olmasına bağlı olarak regresyon analizinde söz konusu tüm değişkenlerin yer alması uygundur.

Değişkenler arası anlamlı ilişkiler olması ile birlikte SPSS Process makrosu ile bağımsız değiş̧kenin bağımlı değişkeni açıklama düzeyi ve aracı değişkenin bu açıklama düzeyi üzerindeki rolünün incelenmesi süreci analiz edilmiştir. Güven aralığının incelenmesinde Bootstrap tekniği kullanılmıştır. Hayes (2018)'in belirttiği kriterler çerçevesinde yorumlama yapılmıştır. Elde edilen bulgular aşağıdaki Tablo 5 'te yer almaktadır. 
Tablo 5: Müşteri İlişkileri Yönetiminin Müşteri Sadakatine Etkisinde Müşteri Memnuniyetinin Aracilik Rolü

\begin{tabular}{|c|c|c|c|c|c|}
\hline \multicolumn{6}{|c|}{ Bağımlı ve Bağımsız Değişkenler Açısında Etkiler } \\
\hline Bağımsız değişken & $\begin{array}{l}\text { Bağımlı } \\
\text { değişken }\end{array}$ & $\begin{array}{c}\text { Anlamlılik } \\
\text { seviyesi }\end{array}$ & $\mathrm{R}^{2}$ & Sabit değer & Katsayı \\
\hline \multicolumn{6}{|c|}{ Toplam model etkisi } \\
\hline $\begin{array}{l}\text { Müşteri ilisskileri } \\
\text { yönetimi }\left(X_{1}\right)\end{array}$ & \multirow{2}{*}{$\begin{array}{l}\text { Müşteri } \\
\text { sadakati }\end{array}$} & \multirow{2}{*}{0,000} & \multirow{2}{*}{0,7248} & \multirow{2}{*}{1,4362} & $\left(\mathrm{X}_{1}\right)=\mathbf{0 , 2 3 4 3}$ \\
\hline $\begin{array}{c}\text { Müşteri } \\
\text { memnuniyeti }\left(\mathrm{X}_{2}\right)\end{array}$ & & & & & $\left(X_{2}\right)=0,4385$ \\
\hline \multicolumn{6}{|c|}{ Bağımsız değişkenin $(\mathrm{X})$ aracı değişken $(\mathrm{M})$ üzerindeki etkisi } \\
\hline $\begin{array}{l}\text { Müşteri ilişkileri } \\
\text { yönetimi }\end{array}$ & $\begin{array}{c}\text { Müşteri } \\
\text { memnuniyeti }\end{array}$ & 0,000 & 0,6916 & 2,8325 & 0,8234 \\
\hline \multicolumn{6}{|c|}{ Bağımsız değişkenin $(\mathrm{X})$ bağımlı değişken $(\mathrm{Y})$ üzerindeki etkisi } \\
\hline $\begin{array}{l}\text { Müşteri ilişkileri } \\
\text { yönetimi }\end{array}$ & $\begin{array}{l}\text { Müssteri } \\
\text { sadakati }\end{array}$ & 0,000 & ,6226 & 2,6781 & $\mathbf{0 , 5 9 5 3}$ \\
\hline \multicolumn{6}{|c|}{ Toplam, Direkt ve Endirekt Etkiler } \\
\hline & & $\begin{array}{c}\text { Anlamlılik } \\
\text { seviyesi }\end{array}$ & Katsay 1 & LLCI & ULCI \\
\hline \multicolumn{6}{|c|}{ Bağımsız değişkenin $(\mathrm{X})$ bağımlı değişken $(\mathrm{Y})$ üzerindeki direkt etkisi } \\
\hline $\begin{array}{l}\text { Müşteri ilişkileri } \\
\text { yönetimi }\end{array}$ & $\begin{array}{l}\text { Müşteri } \\
\text { sadakati }\end{array}$ & 0,000 & ,2343 & , 1725 & ,2961 \\
\hline \multicolumn{6}{|c|}{ Bağımsız değişkenin $(\mathrm{X})$ bağımlı değişken $(\mathrm{Y})$ üzerindeki endirekt etkisi } \\
\hline $\begin{array}{c}\text { Müşteri ilişskileri } \\
\text { yönetimi }\end{array}$ & $\begin{array}{l}\text { Müssteri } \\
\text { sadakati }\end{array}$ & 0,000 & ,3610 & ,3002 & ,4261 \\
\hline \multicolumn{6}{|c|}{ Bağımsız değişkenin (X) bağımlı değişken (Y) üzerindeki toplam etkisi } \\
\hline $\begin{array}{l}\text { Müşteri ilişkileri } \\
\text { yönetimi }\end{array}$ & $\begin{array}{l}\text { Müşteri } \\
\text { sadakati }\end{array}$ & 0,000 & ,5953 & ,5552 & ,6354 \\
\hline
\end{tabular}

Tablo 5 iki farklı bulgu içermektedir. Tablonun ilk kısmı (bağımlı ve bağımsız değişkenler açısından etkiler) değişkenlerin bağımlı ve bağımsız olarak etkileşimini incelerken, tablonun ikinci kısmı ise aracılık etkisinin incelenmesini sağlamaktadır. Tablonun ilk kısmında yer alan bulgular incelendiğinde müşteri ilişkileri yönetimi (X1) ve müşteri memnuniyetinin (X2) müșteri sadakatini (Y) açıklama düzeyi $\% 72,48\left(\mathrm{R}_{2}=0,7248\right.$, Anlamlıl1k $\left.=\mathrm{p} \leq 0,050\right)$ olarak tespit edilmiştir. Müşteri ilişkileri yönetimi ve müşteri memnuniyetinin müşteri sadakati üzerindeki etkisi anlamlıdır. Müşteri ilişkileri yönetiminin(X) müşteri memnuniyetini $(\mathrm{M})$ açıklama düzeyi ise \%69,16 $\left(\mathrm{R}_{2}=0,6916\right.$, Anlamlılı $=p \leq 0,050$ ) olarak tespit edilmiştir. Müşteri ilişkileri yönetiminin aracı değişken olarak kullanılan müşteri memnuniyeti üzerinde anlamlı etkisi olması kurulan modelin anlamlılı̆̆ 1 açısından önemlidir. Müşteri ilişkileri yönetiminin müşteri sadakatine etkisi $\% 62,26\left(\mathrm{R}_{2}=0,6226\right.$, Anlaml111k= $\mathrm{p} \leq 0,050$ ) olarak tespit edilmiştir. Müşteri ilişkileri yönetiminin müşteri sadakatine etki katsayısı toplam modelde 0,2343, direkt etkide ise 0,5953 olarak gerçekleşmektedir. Müşteri ilişkileri yönetiminin müşteri sadakatine olan direkt etkinin toplam model etkisinden daha düşük olması müşteri memnuniyetinin aracilık rolünün olabileceğinin göstergesi olarak kabul edilmektedir. Aracılık etkisinin anlamlılığının incelenmesi için tablonun "toplam, direkt ve endirekt etki" bölümü incelenmektedir. Müşteri ilişkileri yönetiminin müşteri sadakati üzerindeki direkt etkisi ve endirekt etkisinin uygun güven aralığında (LLCI ve ULCI) ve istatistiki olarak anlamlı $(p \leq 0,050)$ olduğu görülmektedir. LLCI ve ULCI değerlerinin nedensellik ilişkilerinde pozitif ya da negatif değer taşıması yani iki değer arasında 0 değerinin yer almaması değişkenler arası nedensellik sonuçlarının güvenilirliği göstermektedir. Elde edilen sonuçlar genel olarak incelendiğinde müşteri ilişkileri yönetiminin ve müşteri memnuniyetinin müşteri sadakatini önemli düzeyde etkilediği görülmektedir. Müşteri ilişkileri yönetimi uygulamalarının ve müşteri memnuniyetinin müşteri sadakatini arttırdığı görülmektedir. Bunun yanında müşteri ilişkileri yönetiminin müşteri sadakatine etkisinde müşteri 
memnuniyetinin kısmi arabuluculuk/aracılık rolünün olduğu tespit edilmiştir. Elde edilen bulgular doğrultusunda $\mathrm{H}_{1}, \mathrm{H}_{2}$ ve $\mathrm{H}_{5}$ hipotezleri kabul edilmiştir.

Tablo 6: Müşteri İlişkileri Yönetiminin Müşteri Sadakatine Etkisinde Müşteri Memnuniyetinin Aracilik Rolü

\begin{tabular}{|c|c|c|c|c|c|}
\hline \multicolumn{6}{|c|}{ Bağımlı Ve Bağımsız Değişkenler Açısında Etkiler } \\
\hline Bağımsız değişken & Bağımlı değişken & $\begin{array}{c}\text { Anlamlilik } \\
\text { seviyesi }\end{array}$ & $\mathrm{R}^{2}$ & Sabit değer & Katsay 1 \\
\hline \multicolumn{6}{|c|}{ Toplam model etkisi } \\
\hline $\begin{array}{l}\text { Satış sonrası destek } \\
\text { hizmetleri }\left(\mathrm{X}_{1}\right)\end{array}$ & \multirow{2}{*}{ Müşteri sadakati } & \multirow{2}{*}{0,000} & \multirow{2}{*}{0,7236} & \multirow{2}{*}{0,8550} & $\left(X_{1}\right)=\mathbf{0 , 8 9 5 9}$ \\
\hline $\begin{array}{c}\text { Müşteri } \\
\text { memnuniyeti }\left(\mathrm{X}_{2}\right)\end{array}$ & & & & & $\left(X_{2}\right)=0,4854$ \\
\hline \multicolumn{6}{|c|}{ Bağımsız değişkenin $(\mathrm{X})$ aracı değişken $(\mathrm{M})$ üzerindeki etkisi } \\
\hline $\begin{array}{l}\text { Satış sonrası destek } \\
\text { hizmetleri }\end{array}$ & $\begin{array}{c}\text { Müssteri } \\
\text { memnuniyeti }\end{array}$ & 0,000 & 0,5748 & 2,3012 & 3,4373 \\
\hline \multicolumn{6}{|c|}{ Bağımsız değişkenin $(\mathrm{X})$ bağımlı değişken $(\mathrm{Y})$ üzerindeki etkisi } \\
\hline $\begin{array}{c}\text { Satış sonrası destek } \\
\text { hizmetleri }\end{array}$ & Müşteri sadakati & 0,000 & ,5510 & 1,9721 & 2,5645 \\
\hline \multicolumn{6}{|c|}{ Toplam, Direkt ve Endirekt Etkiler } \\
\hline & & & Katsayı & LLCI & ULCI \\
\hline \multicolumn{6}{|c|}{ Bağımsız değişkenin $(\mathrm{X})$ bağımlı değişken $(\mathrm{Y})$ üzerindeki direkt etkisi } \\
\hline $\begin{array}{c}\text { Satış sonrası destek } \\
\text { hizmetleri }\end{array}$ & Müşteri s & akati & 8959 & 6546 & 1,1373 \\
\hline \multicolumn{6}{|c|}{ Bağımsız değişkenin (X) bağımlı değişken (Y) üzerindeki endirekt etkisi } \\
\hline $\begin{array}{c}\text { Satı̧s sonrası destek } \\
\text { hizmetleri }\end{array}$ & Müşteri s & akati & 1,6686 & 1,3558 & 1,9975 \\
\hline \multicolumn{6}{|c|}{ Bağımsız değişkenin $(\mathrm{X})$ bağımlı değişken $(\mathrm{Y})$ üzerindeki toplam etkisi } \\
\hline $\begin{array}{c}\text { Satış sonrası destek } \\
\text { hizmetleri }\end{array}$ & Müşteri s & akati & 2,5645 & 2,3641 & 2,7649 \\
\hline
\end{tabular}

Tablo 6 iki farklı bulgu içermektedir. Tablonun ilk kısmı (bağımlı ve bağımsız değişkenler açısından etkiler) değişkenlerin bağımlı ve bağımsız olarak etkileşimini incelerken, tablonun ikinci kısmı ise aracılık etkisinin incelenmesini sağlamaktadır. Tablonun ilk kısmında yer alan bulgular incelendiğinde satış sonrası destek hizmetleri (X1) ve müşteri memnuniyetinin (X2) müşteri sadakatini (Y) açıklama düzeyi $\% 72,36\left(\mathrm{R}_{2}=0,7236\right.$, Anlamlılık $\left.=\mathrm{p} \leq 0,050\right)$ olarak tespit edilmiştir. Satış sonrası destek hizmetleri ve müşteri memnuniyetinin müşteri sadakati üzerindeki etkisi anlamlıdır. Satış sonrası destek hizmetleri (X) müşteri memnuniyetini (M) açıklama düzeyi ise $\% 57,48\left(\mathrm{R}_{2}=0,5748\right.$, Anlamlılı $\left.=\mathrm{p} \leq 0,050\right)$ olarak tespit edilmiştir. Satış sonrası destek hizmetlerinin aracı değişken olarak kullanılan müşteri memnuniyeti üzerinde anlamlı etkisi olması kurulan modelin anlamlılığı açısından önemlidir. Satış sonrası destek hizmetlerinin müşteri sadakatine etkisi $\% 55,10$ $\left(\mathrm{R}_{2}=0,5510\right.$, Anlaml11 $\left.\mathrm{k}=\mathrm{p} \leq 0,050\right)$ olarak tespit edilmiştir. Satış sonrası destek hizmetlerinin müşteri sadakatine etki katsayısı toplam modelde 0,8959, direkt olarak ise 2,5645 olarak gerçekleşmektedir. Satış sonrası destek hizmetlerinin müşteri sadakatine olan direkt etkinin toplam model etkisinden belirgin şekilde düşük olması müşteri memnuniyetinin aracılık rolünün olabileceğinin göstergesi olarak kabul edilmektedir. Aracılık etkisinin anlamlılı̆̆ının incelenmesi için tablonun "toplam, direkt ve endirekt etki" bölümü incelenmektedir. Satış sonrası destek hizmetlerinin müşteri sadakati üzerindeki direkt etkisi ve endirekt etkisinin uygun güven aralığında (LLCI ve ULCI) ve istatistiki olarak anlamlı $(\mathrm{p} \leq 0,050)$ olduğu görülmektedir. LLCI ve ULCI değerlerinin nedensellik ilişkilerinde pozitif ya da negatif değer taşıması yani iki değer arasında 0 değerinin yer almaması değişkenler 
arası nedensellik sonuçlarının güvenilirliği göstermektedir. Tablodaki bulgular incelendiğinde LLCI ve ULCI değerlerinin arasında 0 noktasının olmadığı ve değerlerin pozitif alanda olduğu görülmektedir. Elde edilen sonuçlar genel olarak incelendiğinde müşteri ilişkileri yönetiminin ve müşteri memnuniyetinin müşteri sadakatini önemli düzeyde etkilediği görülmektedir. Satış sonrası destek hizmetlerinin ve müşteri memnuniyetinin müşteri sadakatine etkisi pozitif yöndedir. Bunun yanında satış sonrası destek hizmetlerinin müşteri sadakatine etkisinde müşteri memnuniyetinin kısmi arabuluculuk/aracılık rolü olduğu tespit edilmiştir. Elde edilen bulgular doğrultusunda $\mathrm{H}_{3}, \mathrm{H}_{4}$ ve $\mathrm{H}_{6}$ hipotezleri kabul edilmiştir.

\section{Sonuç, Tartışma ve Öneri}

Araştırmanın amacı, satış sonrası destek hizmetleri ve müşteri ilişkileri yönetimi uygulamalarının müşterilerin memnuniyeti ve müşterilerin sadakatinin oluşmasındaki etkisinin tespit edilmesidir. Ayrıca araştırma kapsamında müşteri memnuniyetinin; satış sonrası destek hizmetlerinin ve müşteri ilişkileri yönetiminin müşteri sadakatinde aracılık rolünün olup olmadığının tespit edilmesi amaçlanmıştır. Araştırmada yapılan analizler sonucunda satış sonrası destek hizmetlerinin müşteri memnuniyeti ve müşteri sadakati üzerinde yüksek düzeyde etkisinin olduğu tespit edilmiştir. Bunun yanında satış sonrası destek hizmetlerinin müşteri sadakati oluşturmadaki etkisinde müşteri memnuniyetinin kısmi aracılık rolünün olduğu görülmüştür. Beyaz eşya sektöründen alışveriş yapan müşteriler için satış sonrası destek hizmetlerinin memnuniyet ve sadakat oluşturma aracı olduğunu ifade etmek mümkündür. Müşteri ilişkileri yönetiminin müşteri memnuniyeti ve müşteri sadakatini olumlu yönde etkilediği sonucuna ulaşılmıştır. Ayrıca müşteri ilişkileri yönetiminin müşteri sadakatini arttırmasında müşteri memnuniyetinin kısmi arabulucuk/aracılık rolünün olduğu görülmektedir. Beyaz eşya sektöründe müşteri ilişkileri yönetimi uygulamalarının müşteri sadakati ve müşteri memnuniyeti oluşturmada önemli bir faktör olduğunu ifade etmek mümkündür. Elde edilen sonuçlar genel olarak yorumlandığında; özellikle beyaz eşya sektöründe uygulanacak satış sonrası destek hizmetlerinin yeterli olarak algılanması ve müşteri ilişkileri yönetiminin uygun şekilde yürütülmesi, müşterilerin memnuniyet düzeylerinin artmasını, buna bağlı olarak da müşteri sadakatinin oluşmasını sağladığını ifade etmek mümkündür. Araştırmada elde edilen bulgular ve alanyazında daha önce elde edilmiş sonuçlar karşılaştırıldığında değişkenler arası ikili ilişkilerin benzerlik gösterdiği görülmektedir. Satış sonrası destek hizmetlerinin müşteri memnuniyeti ve müsşteri sadakati oluşturması açısından elde edilen bulgular Çelik ve Bengül (2008), Özgören(2012), Yıldırır (2014) Özgüner ve Kurtuldu (2015) ile Güllülü ve Bilgili (2011) tarafından yapılan araştırma sonuçları ile benzerdir. Müşteri ilişkileri yönetiminin müşteri memnuniyeti ve müşteri sadakatine olan etkileri hakkındaki sonuçlar ise Demirel (2007), Sapura (2018), Ajman ve Rehman (2019), Kristian ve Panjaitan (2014) ve Long vd. (2013) tarafindan yapılan araştırma sonuçları ile benzerlik taşımaktadır.

Araştırma sonucunda elde edilen bulgular ışı̆̆ında satış sonrası destek hizmetleri sağlayan ve müşteri ilişkileri yönetimini uygun şekilde sağlayan firmaları müşterilerini daha fazla memnun edebileceği, bunun sonucunda da müşteri sadakati oluşturabileceğini ifade etmek mümkündür. Müşteri sadakatinin oluşması firmalar için uygun bir rekabet aracı olabilmektedir. Araştırmada elde edilen bulgular beyaz eşya sektörü ve İstanbul açısından sonuçlar sunabilmektedir. Konuyla ilgili olarak yapılacak araştırmalarda söz konusu kısıtları göz önünde bulundurulması, özellikle Covid-19 pandemisi sonrasında müşteri sadakatinin nasıl değiştiğini incelemeleri önerilmektedir.

\section{Kaynakça}

Bakırtaş, H. (2013). Müşteri iliş̧kileri yönetimi (Ed: Necdet Timur Gülfidan Barış) içinde 3-23). Müşteri iliş̧kileri yönetimi: tanımı, kapsamı, önemi, Anadolu Üniversitesi Yayını. 
Bolton, R., \& K.N. Lemon (1999). A dynamic model of customers' usage of services: Usage as an antecedent and consequence of satisfaction. Journal of Marketing Research, 36 (2), 171-86.

Chaudhuri, A. (1999). The relationship of brand attitudes and brand performance: The role of brand loyalty. The Journal of Marketing Management, 9(3), 1-9.

Chen, S. C., (2012). The customer satisfaction-loyalty relation in an interactive e-service setting: The mediators. J. Retail. Consum. Serv. 19 (2), 202-210.

Cıranoğlu, M. (2019). Tüketicilerin satış sonrası hizmetlerden duydukları memnuniyetin satın alınan ürünün algılanan değerine etkisi: beyaz eşya ürünleri üzerine bir araştırma. International Journal of Social Inquiry, 12(1), 65-98.

Cronin, J. J. Jr. \& S. A. Taylor (1994). SERVPERF versus SERVQUAL: reconciling performancebased and perceptions-minus-expectations measurement of service quality. Journal of Marketing, 58(1), 125-131.

Çelik, H. \& Bengül, S. S. (2008). Satış sonrası hizmetler ve ürün garantilerinin müşteri tatmini, memnuniyeti ve marka sadakati üzerindeki etkileri. H. ̈̈. Íktisadi ve İdari Bilimler Fakültesi Dergisi, 26(2), 105-120.

Demir, F. O., \& Kırdar, Y. (2007). Müşteri ilişkileri yönetimi: CRM. Review of Social, Economic \& Business Studies, 7(8), 293-308.

Demir, M. Ö. (2012). Marka sadakatinin ölçülmesi: Niyete bağlı tutumsal ölçek ile satın alma sırasına dayalı davranışsal ölçeğin karşılaştırılması. İstanbul Üniversitesi İşletme Fakültesi Dergisi, 41(1), 103-128.

Demirel, Y. (2007). Türk bankacıllk sektöründe müşteri ilişkileri yönetiminin müşteri sadakati üzerine etkisi. Kocaeli Üniversitesi Sosyal Bilimler Enstitüsü Dergisi 13(1), 56-81.

Doğan, B., Buldu, A., Demir, Ö. \& Ceren, B. E. (2018). Sigortacıllk sektöründe müşteri ilişki yönetimi için kümeleme analizi. Karaelmas Fen ve Mühendislik Dergisi, 8(1), 11-18.

Eminler, O., Altunışık, R. \& Eskiler, E. (2019). Müşteri memnuniyeti, duygusal yakınlık, müşteri sadakati ve ağızdan ağıza pazarlama arasındaki ilişkilerin incelenmesi: Perakende sektörü örneği. BMIJ, 7(4), 1905-1922.

George, D., \& Mallery, M. (2010). Spss for windows step by step: a simple guide and reference, 17.0 update (10a ed.), Pearson

Güllülü, U. \& Bilgili B. (2011). Satış sonrası hizmetlerde kalite algısı ve müşteri memnuniyeti ilişkisi. Pazarlama ve Pazarlama Araştırmaları Dergisi, 7, 23-41.

Hair, J. Black, W., Babin, B. \& Anderson, R. (2014). Multivariate data analysis. 7. Ed. Pearson Education Limited.

Hayes, A. F. (2018). Introduction to mediation, moderation, and conditional process analysis. The Guilford Press.

Kasiria, L. A., Chengb, K. T. G., Sambasivanc, M. \& Sidind S. M. (2017). Integration of standardization and customization: impact on service quality, customer satisfaction, and loyalty. Journal of Retailing and Consumer Services 35, 91-97.

Kristian, B. F. \& Panjaitan, H. (2014). Analysis of customer loyalty through total quality service, customer relationship management and customer satisfaction. International Journal of Evaluation and Research in Education, 3(3), 142-151. 
Kumar, V., Pozza, I. D. \& Ganesh, J., (2013). Revisiting the satisfaction-loyalty relationship: empirical generalizations and directions for future research. J. Retail. 89(3), 246-262.

Lee, H., Y.Lee \& D. Yoo (2000). The determinants of perceived service quality and its relationship with satisfaction. Journal of Services Marketing, 14(3), 217- 231.

Long, C. S., Khlafinezhad, R. Khairuzzaman, W. İsmail \& W. Rasid, S. Z. A. (2013). Impact of CRM factors on customer satisfaction and loyalty. Asian Social Science, 9(10), 247-253.

Meesalaa, A. \& Paul, J. (2018). Service quality, consumer satisfaction and loyalty in hospitals: thinking for the future. Journal of Retailing and Consumer Services, 40, 261-269.

Nyadzayo, M. W. \& Khajehzadeh, S. (2016). The antecedents of customer loyalty: a moderated mediation model of customer relationship management quality and brand image. Journal of Retailing and Consumer Services, 30, 262-270.

Özgören, F. (2012). Satış sonrası hizmetin müşteri sadakatine etkisi ve Ericsson örneği. Marmara Sosyal Araştırmalar Dergisi, 2(2012), 1-23.

Özgüner, Z. \& Kurtuldu, H. S. (2015). Yetkili servislerde verilen satış sonrası hizmetlerin, müşteri memnuniyetine etkisi: İstanbul ili otomotiv sektöründe bir uygulama. Çankırı Karatekin Üniversitesi İktisadi ve İdari Bilimler Fakültesi Dergisi, 5(2), 569-589.

Paul, J., Sankaranarayanan, K. G. \& Mekoth, N. (2016). Consumer satisfaction in retail stores: Theory and implications. International Journal of Consumer Studies, 40, 635-642.

Rivera, J.J., Bigne, E. \& Curras-Perez, R. (2016). Effects of corporate social responsibility perception on consumer satisfaction with the brand. Spanish Journal of Marketing, 20, 104-114.

Sadaf Ajmal \& Ur -Rehman S. (2019). An implementation of customer relationship management and customer satisfaction in banking sector of quetta, balochistan, international business research. Canadian Center of Science and Education, 12(10), 26-37.

Saputra, S. (2018). The effect of customer relationship management (CRM) on bank customer loyalty through satisfaction as mediating variable: Evidence in Batam, Indonesia. Advances in Social Science, Education and Humanities Research, 306, 146-151.

Sekaran, U. (2003). Research methods for business a skill-building approach. 4. Bask1. John Wiley \& Sons. Inc.

Silva, F. J. C., Camacho, M. Á. R., Vázquez, M. V. \& Florencio, B. P. (2016). Value co-creation and customer loyalty. Journal of Business Research, 69, 1621-1625.

Sivadas, E. \& Baker-Prewitt, J. L. (2000). An examination of the relationship between service quality, customer satisfaction, and store loyalty. International Journal of Retail \& Distribution Management, 28(2), 73- 82.

Sofi, M. R. Bashir, I. Parry \& M. A. Dar, A. (2020). The effect of customer relationship management (CRM) dimensions on hotel customer's satisfaction in Kashmir. International Journal of Tourism Cities, https://doi.org/10.1108/IJTC-06-2019-0075.

Spreng, R.A., S.B. Mac Kenzie \& R.W Olshavsky (1996). Reexamination of the Determinants of Consumer Satisfaction. Journal of Marketing, 60(3), 15-33.

Suh, J.C. \& Yi, Y., (2006). When brand attitudes affect the customer satisfaction-loyalty relation: the moderating role of product involvement. J. Consum. Psychol. 16 (2), 145-155. 
Şimşek, H. (2017). Marka özgünlügünün ağızdan ă̆ıza pazarlama ile ilişkisinde müşteri memnuniyetinin aracılık rolü: hazır giyim sektöründe bir araştırma. Haliç Üniversitesi Sosyal Bilimler Enstitüsü, Doktora Tezi.

Tabachnick, B.G. \& L.S. Fidell (2013). Using multivariate statistics (sixth ed.). New York: Pearson.

Tüzüntürk, S. Dülgeroğlu, İ. \& Gönüller, Ş. (2016). Avrupa müşteri memnuniyeti endeksi modeli: Marmara Bölgesi'nde bir lüks otomobil markasının satış sonrası hizmetlerinin bulguları. Akademik Bakış Dergisi, 55, 109-131.

Yıldırır, S. C. (2014). Satış öncesi ve satış sonrası müşteri hizmetlerinin müşteri sadakati üzerindeki etkisinin araştırılması. Bitlis Eren Üniversitesi Sosyal Bilimler Enstitüsü Dergisi, 3(2), 6583. 